\title{
Theoretical framework of clinical reasoning in neurological physiotherapy: NeuroQR
}

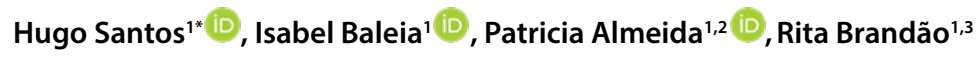 \\ 'Escola Superior de Saúde do Alcoitão, Alcabideche, Portugal; \\ ${ }^{2}$ Hanze University of Applied Sciences Groningen, Países Baixos; \\ ${ }^{3}$ Escola Superior de Saúde Atlântica, Barcarena, Portugal. \\ *Autor correspondente/Corresponding author: hugo.santos@essa.scml.pt
}

Recebido/Received: 25-03-2021; Revisto/Revised: 29-04-2021; Aceite/Accepted: 13-07-2021

\section{Resumo}

A Fisioterapia Neurológica (FN), intervém nos indivíduos que sofrem de doenças que afetam o sistema nervoso e que provocam distúrbios motores, que se traduzem em alterações complexas do movimento e da funcionalidade. A FN é uma área científica que evoluiu fortemente nas últimas décadas. O conhecimento adquirido ao longo dos anos exige um raciocínio clínico sólido e uma gestão bem estruturada para a sua incorporação adequada na prática clínica. Embora a literatura atual forneça muitas informações sobre o raciocínio clínico e a tomada de decisão em fisioterapia, são poucos os artigos que discutem o raciocínio clínico específico da FN. O objetivo deste artigo é apresentar um quadro referencial teórico para o raciocínio clínico do fisioterapeuta que atua junto aos utentes com disfunções motoras e funcionais decorrentes de distúrbios neurológicos. O modelo descrito está dividido em 4 níveis - conceitos, abordagens, métodos e técnicas, foi construído pelo grupo de FN do departamento da ESSAlcoitão e tem por base outros quadros referenciais previamente publicados.

Palavras-chave: fisioterapia neurológica, neurorreabilitação, quadro referencial, modelo conceptual, raciocínio clínico.

\begin{abstract}
Neurological physiotherapy (NF) assists individuals who suffer from nervous system diseases that cause motor disorders to manage complex changes in movement and regain functionality. NF is a scientific area that has grown in recent decades. The knowledge acquired over the years requires solid clinical reasoning and well-structured management for its proper incorporation into clinical practice. Although the literature provides much information about clinical reasoning and decision-making in physiotherapy, few articles discuss the specific clinical reasoning of NF. The aim of this article is to present a theoretical framework for the clinical reasoning of the physiotherapist who works with individuals who have motor disorders and loss of functionality resulting from neurological disorders. The framework described is divided into 4 dimensions: concepts, approaches, methods and techniques. It was built by the Physiotherapy Department of Alcoitão Health School and is based on previously published frameworks.
\end{abstract}

Keywords: neurological Physiotherapy; Neurorehabilitation; Framework; Conceptual model; Clinical reasoning.

\section{INTRODUÇÃO}

A Fisioterapia Neurológica (FN), também chamada de fisioterapia neuromuscular ou de fisioterapia neurofuncional, intervém nos indivíduos que sofrem de doenças que afetam o sistema nervoso e que provocam distúrbios motores, que se traduzem em alterações complexas do movimento e da funcionalidade. O objetivo da FN é avaliar essas limitações e tentar ativar sinergias motoras o mais funcionais possíveis, através de estratégias de recuperação e/ou de compensação. Nesse sentido, na FN o utente é estimulado de forma a conseguir restabelecer as suas funções ou a readaptar-se à sua nova condição, promovendo a ativação voluntária do

\section{INTRODUCTION}

Neurological physiotherapy (NPT), also known as neuromuscular physiotherapy, is a functional neurological therapy specialization that helps restore movement and function to individuals affected by a nervous system injury, illness or disability. The aims are to assess existing limitations and disabilities and to restore and activate motor synergies to maximize functional recovery by the use of restorative or adaptive strategies. With NPT, patients are stimulated to reacquire function (restorative) or to adapt to the new movement condition (adaptive) through voluntary movement activation, independence and autonomy training, leading to improved quality of life.

NPT is a scientific discipline with substantial growth in 
movimento, a independência e a autonomia, melhorando, consequentemente, a sua qualidade de vida.

A FN é uma área científica que evoluiu fortemente nas últimas décadas. Essa evolução pode ser explicada, em grande parte, pelo avanço simultâneo do conhecimento nas neurociências, controlo motor e (re)aprendizagem motora. Esse fato tem levado ao desenvolvimento de mais técnicas de avaliação e tratamento e novas considerações para a prática.

No entanto, esse conhecimento adquirido exige um raciocínio clínico sólido e uma gestão bem estruturada para a sua incorporação adequada na prática clínica. Embora a literatura atual forneça muitas informações sobre o raciocínio clínico e a tomada de decisão em fisioterapia, são poucos os artigos que discutem o raciocínio clínico específico da FN (Dimitriadis, Skoutelis, \& Tsipra, 2016). O objetivo deste artigo é apresentar um quadro referencial teórico (em inglês framework) para o raciocínio clínico do fisioterapeuta que atua junto aos utentes com disfunções motoras e funcionais decorrentes de distúrbios neurológicos. O modelo descrito está dividido em 4 níveis - conceitos, abordagens, métodos e técnicas, foi construído pelo grupo de FN do departamento da ESSAlcoitão e tem por base outros quadros referenciais previamente publicados (Dimitriadis et al., 2016; Eckhardt et al., 2018; Fell, Lunnen, \& Rauk, 2018; Lennon, Ramdharry, \& Verheyden, 2018; Michielsen, Vaughan-Graham, Holland, Magri, \& Suzuki, 2019).

\section{RACIOCÍNIO CLÍNICO}

Antes de partir para a descrição do modelo será importante fazermos uma pequena introdução sobre raciocínio clínico.

O raciocínio é uma operação lógica discursiva e mental. Neste, o intelecto humano utiliza uma ou mais proposições, para concluir, através de mecanismos de comparações e abstrações, quais são os dados que levam às respostas verdadeiras, falsas ou prováveis. Com o raciocínio, das premissas chegamos a conclusões. Raciocínio clínico em fisioterapia é o processo pelo qual o fisioterapeuta interage com o utente, recolhendo informações, gerando e testando hipóteses e determinando o diagnóstico e o tratamento ideal com base nas informações obtidas. Foi definido por Higgs e Jones (2008) como "um processo inferencial usado por profissionais para recolher e avaliar dados e fazer julgamentos sobre o diagnóstico e a gestão dos problemas do utente" (Higgs \& Jones, 2008).

Assim, muito resumidamente, o raciocínio clínico em FN consiste em analisar os dados obtidos no exame neurofuncional do utente de forma a chegar às melhores hipóteses/conclusões sobre a resolução dos problemas relacionados com o movimento dos utentes.

Desde 1940 foram aparecendo várias modelos/ abordagens de intervenção (abordagem de Bobath, facilitação neuroproprioceptiva, treino orientado para a tarefa, terapia induzida por restrição do movimento, entre tantas outras) que influenciaram a forma como se elabora o raciocínio clínico em FN e consequentemente as intervenções que se usam. Ainda hoje em dia, os neurofisioterapeutas ou fisioterapeutas neurofuncionais, implementam intervenções com base nas abordagens terapêuticas preferidas. No entanto, até ao momento, não há evidências que sugiram que uma abordagem terapêutica seja superior a outra. A intervenção aplicada recent decades. This development is greatly associated with scientific developments in the neurosciences, motor control and motor (re)learning understanding. New evidence-based neuroscience has promoted the development of new practice considerations and more accurate clinical reasoning with efficient scientific-based physiotherapy assessment and treatment approaches.

The use of this scientific information requires solid clinical reasoning with complex critical analysis and decision-making to transfer adequately to contextualized practice. Despite the existence of sufficient and updated literature regarding clinical reasoning and decision-making in physiotherapy, only a few articles discuss the specificities of clinical reasoning for NPT (e.g. Dimitriadis, Skoutelis, \& Tsipra, 2016). This special report aims to present a clinical reasoning framework for physiotherapists working with patients who have movement and function disorders caused by a nervous system injury, illness or disability. The framework is structured in four dimensions: concepts, approaches, methods and techniques. It was developed by the Physiotherapy Department of Alcoitão Health School and is based on other published frameworks (Dimitriadis et al., 2016; Eckhardt et al., 2018; Fell, Lunnen, \& Rauk, 2018; Lennon, Ramdharry, \& Verheyden, 2018; Michielsen, Vaughan-Graham, Holland, Magri, \& Suzuki, 2019) combined with a teaching and learning pedagogical model (Redondo, 2016).

\section{CLINICAL REASONING}

Before describing the framework specificities, a brief discussion of clinical reasoning is offered.

Reasoning is a mental logical-discursive operation. The human intellect uses one or more propositions and by means of comparison and abstraction reaches conclusions about which ones are true, false or more likely. This is the basic mechanism the mind uses to move from premises to conclusions. Clinical reasoning in physiotherapy is "an inferential process used by practitioners to collect and evaluate data and to make judgments about the diagnosis and management of patient problems" (Higgs \& Jones, 2008). In practice, this is the process by which the physiotherapist, in collaboration with the patient, gathers different types of clinical and contextual information, creates hypothesis tests (propositions) and critically analyses them (comparing and abstracting) to determine the accurate diagnosis and treatment or solutions needed.

Specifically, in NPT, clinical reasoning consists of analysing data obtained during the neurofunctional exam and assessment to reach the most accurate hypothesis and decision to restore adequate movement, independence and contextualized autonomy.

Since 1940, a number of diverse physiotherapy interventions have been introduced, such as the Bobath concept, proprioceptive neuromuscular facilitation, task-oriented approaches, and constraint-induced movement therapy. These approaches have influenced NPT clinical reasoning and led to current practices, including approaches based on these earlier preferred methods. Currently, clinical intervention is sustained in scientific neuroscience information and structured according to theoretical and practical components transversal to different approaches (Nielsen et al., 2015). However, despite intense 
na prática, decorrente da evolução das ciências básicas, é atualmente composta por vários componentes teórico-práticos que se repetem nas várias abordagens que foram surgindo (Nielsen et al., 2015).

Assim, existe a necessidade de criar e implementar um quadro referencial universal da $\mathrm{FN}$, baseado na melhor evidência científica e nos vários componentes que se repetem nas diferentes abordagens, que nos permita fundamentar $o$ raciocínio clínico e uniformizar as nossas intervenções. Este trabalho tem sido desenvolvido por vários autores, sendo que a IBITA (International Bobath Instructors Training Association) tem sido uma das organizações que mais contribuíram para o desenvolvimento desses quadros referenciais (Eckhardt et al., 2018; Michielsen et al., 2019)

Os quadros referenciais não devem ser estruturas estanques e devem absorver os resultados dos estudos que se vão produzindo na $\mathrm{FN}$ e nas áreas afins. Por sua vez esses estudos devem ter como objetivo avaliar os princípios ativos ou as componentes que constituem a $\mathrm{FN}$, e não as abordagens em si, uma vez que as semelhanças entre as abordagens podem realmente superar as suas diferenças.

\section{O QUADRO REFERENCIAL NEUROQR}

$\mathrm{O}$ quadro referencial da $\mathrm{FN}$ que aqui apresentamos e ao qual demos o nome de NeuroQR (Fig. 1), é baseado no modelo utilizado nas metodologias de ensino-aprendizagem. Os especialistas da área da pedagogia falam em 4 níveis metodológicos. Sendo que encontramos, do mais geral para o mais específico, o nível dos conceitos, o nível das abordagens, o nível dos métodos e o nível das técnicas. Uma técnica leva a cabo um método que é coerente com uma abordagem, a qual se baseia em conceitos teóricos fundamentais (Redondo, 2016).

No que diz respeito ao modelo NeuroQR, no nível dos conceitos descrevem-se os conceitos fundamentais que o neurofisioterapeuta deve dominar para desenvolver um raciocínio clínico eficaz. O nível das abordagens são as ideias capitais que devem sustentar a prática do neurofisioterapeuta na interação com o utente. O nível dos métodos descreve os procedimentos gerais para a implementação das abordagens. Por fim no nível das técnicas estão identificadas as estratégias práticas que se vão utilizar para implementar os métodos.

\subsection{NÍVEL DOS CONCEITOS}

Os conceitos fundamentais que devem fazer parte da "bagagem" teórica do fisioterapeuta neurofuncional são: neuroplasticidade, modelo conceptual da funcionalidade segundo a Classificação Internacional da Funcionalidade (CIF), comportamento motor e aprendizagem motora, disfunções neurológicas e metodologias de investigação e estatística.

Embora a neuroplasticidade ocorra de uma forma espontânea após uma lesão cerebral, os avanços nos exames de neuro-imagem permitiram confirmar que a plasticidade neural, definida como mudanças duradouras na estrutura e função do sistema nervoso, também ocorre como resultado da experiência e da fisioterapia. A reabilitação parece ser mais efetiva se a intervenção tiver em consideração os princípios da neuroplasticidade e o neurofisioterapeuta deve ter um conhecimento profundo destes princípios. research, there is no evidence-based superiority among the different approaches or a universal frame of reference.

Therefore, the development of a framework for NPT sustained by the latest scientific information and based on the different components transversal to several approaches is needed to steer clinical reasoning and benchmark approaches. Several authors initiated this work, and the International Bobath Instructors Training Association (IBITA) has made major contributions to the development of this framework (Eckhardt et al., 2018; Michielsen et al., 2019).

Frameworks should be dynamic and not static and rigid. Especially in neurology, frameworks should be liquid and permeable to the latest developments in the field of NPT and related areas. Instead of researching approaches per se, this research for a framework aims to evaluate principles and components associated with NPT. This will highlight the similarities and, therefore, the transversal principles and components, not the differences among approaches.

\section{NEUROQR FRAMEWORK}

The name of the NeuroQR framework (Fig. 1) comes from the Portuguese name "Neuro Quadro Referencial". The framework is a teaching and learning pedagogical model based on previous frameworks. Specialists in education refer to four methodological means of organizing education. From general to specific, these dimensions are concepts, approaches, methods and techniques; interestingly, these are similar to the framework proposed by IBITA. They are interrelated where a technique implements a method that is guided by an approach supported by fundamental theoretical concepts (Redondo, 2016).

Translating this into physiotherapy and to the NeuroQR framework first, at the concepts level, we find the fundamental concepts a physiotherapist should master for accurate and efficient clinical reasoning. Second, at the approach level, there are the major guiding principles and ideas orienting collaboration and intervention with the patient. Third, the methods level describes the intervention plans to implement, and finally, at the techniques level, the practical strategies to implement the plans are identified.

\subsection{CONCEPTS LEVEL}

The fundamental concepts belonging to the neurophysiotherapist's body of knowledge are neuroplasticity, international classification of functioning, disability and health, motor control and behaviour, motor learning, neurological dysfunction and research methods and analysis.

Neuroplasticity is a regular biological and spontaneous mechanism that is also present after a neurological disorder. However, neuroimaging research has confirmed that neural plasticity can address long-term changes in nervous system structure and function and is enhanced by physiotherapy intervention. The results are more effective if the intervention considers and applies in practice neuroplasticity principles. Therefore, neurophysiotherapists should have a solid body of knowledge in this field.

The International Classification of Functioning, Disability and Health (ICF) model integrates all key concepts of the 


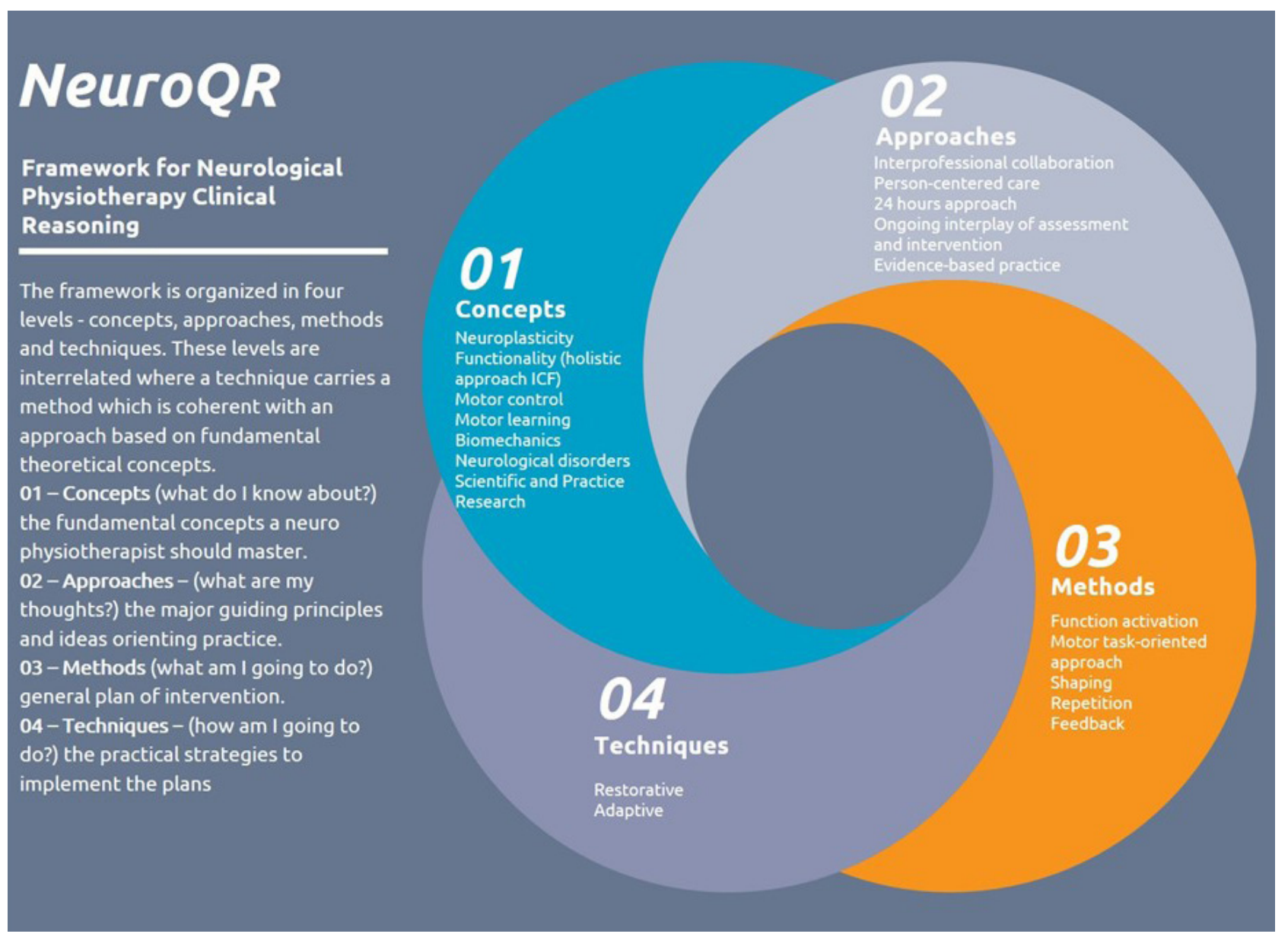

Figura/Figure 1: Representação esquemática do quadro referencial NeuroQR /Schematic representation of the NeuroQR Framework

A CIF propõe uma abordagem à saúde do indivíduo, ou ao processo incapacitante, através de um modelo biopsicossocial que incorpora componentes da saúde nos níveis físico e social. Esta proposta transcende o modelo biomédico baseado na etiologia da doença, evoluindo para um modelo tridimensional: biomédico, psicológico e social. Neste caso, cada nível age e sofre as ações dos outros, e todos eles são influenciados pelo meio ambiente.

O controlo motor é a área da ciência que explora como o sistema nervoso interage com outras partes do corpo e o ambiente de forma a produzir ações voluntárias coordenadas e eficazes, sendo fundamental para o neurofisioterapeuta perceber como os diferentes sistemas dentro do sistema nervoso interagem para produzir o movimento e executar as tarefas motoras. Além do controlo motor o neurofisioterapeuta deve possuir conhecimentos avançados sobre a aprendizagem motora, esta área do conhecimento providencia princípios sobre como estruturar as sessões e melhorar os aspetos relacionados com a performance motora.

É essencial que o neurofisioterapeuta possua conhecimentos de neuroanatomia funcional e clínica. O exercício de associação dos sintomas e sinais neurológicos apresentados pelo utente com o tipo de função alterada e com a estrutura anatómica a ela associada é a base do raciocínio clínico em FN.

A fisioterapia é uma área do conhecimento e uma profissão fortemente fundamentada e suportada cientificamente, como medical, functional, and social models of disability and provides the best potential for use as a tridimensional integrative conceptual framework for clinical reasoning. It reaches beyond the biomedical model centred on the disease by considering the intrinsic relationships among body structures and functions, activities and participation and the influence of personal and environmental factors.

Motor Control is a science that studies and explains how the nervous system interacts with other body parts and the environment to produce coordinated voluntary movement associated with functional activities. It is a fundamental science in a neurophysiotherapist's body of knowledge to understand and stimulate the correct nervous system interactions to produce movement and execute tasks. Associated with motor control, the principles and theories of Motor Learning are also important tools for the neurophysiotherapist. This knowledge optimizes the intervention session structure and motor performance outcomes. Both sciences require an advanced understanding of clinical and functional neuroanatomy and its correlation with the neurological signs and symptoms presented by the patient. This associative reasoning is one of the pillars for NPT clinical reasoning.

Physiotherapy as a science and a profession is strongly supported by scientific evidence and theories. As such, physiotherapists, in addition to clinical competencies, are required to understand research methods, data analysis, interpretation and translation into practice to have scientific 
tal o neurofisioterapeuta deve dominar os conceitos associados às metodologias de investigação e à estatística de forma a exercer uma prática o mais informada possível na melhor evidência.

\subsection{NÍVEL DAS ABORDAGENS}

O nível das abordagens corresponde ao nível em que o modelo transporta o essencial dos conceitos fundamentais para as ideias e pensamentos que devem estabelecer o raciocínio clínico da FN. Assim a abordagem do neurofisioterapeuta deve fundamentar-se nas ideias capitais que se seguem: trabalho em equipa, intervenção centrada na pessoa, intervenção nas 24 horas, interação avaliação-intervenção e prática baseada na evidência.

As pessoas com disfunções neurológicas apresentam, a maioria das vezes, uma grande variedade de problemas complexos que cobrem muitos domínios diferentes e que, muitas vezes, duram muito tempo. Consequentemente, estes utentes precisam de uma equipa com profissionais diferentes. Cada um dos profissionais irá cuidar de pequenas partes do conjunto global de dificuldades. Para garantir que todos os problemas sejam considerados e que todos os envolvidos trabalhem de forma eficiente e eficaz, deve-se ter um sistema de cooperação e colaboração, uma equipa de trabalho (Wade, 2020). O neurofisioterapeuta deve perceber qual o seu papel nesse sistema de cooperação e saber trabalhar em equipa de forma a otimizar a sua intervenção.

A intervenção centrada na pessoa pode ser definida como a filosofia do cuidar que encoraja e suporta o utente e os seus cuidadores a desenvolverem o conhecimento, as competências e a confiança que necessitam para gerir eficazmente a sua saúde e tomarem decisões informadas acerca da sua saúde. Intervir segundo esta filosofia significa que existe um diálogo constante e interativo entre o utente e o fisioterapeuta, de tal forma que o utente é envolvido na tomada de decisão ao longo de toda a intervenção. Dois conceitos associados à intervenção centrada na pessoa são a autogestão e a promoção da saúde (Lennon et al., 2018).

A intervenção nas $24 \mathrm{~h}$ baseia-se na transferência do que o utente praticou e aprendeu na sessão de intervenção para a sua rotina diária. Integra a pessoa, os seus familiares, todas os profissionais envolvidos, o ajuste do ambiente e a prescrição de ajudas técnicas no processo de reabilitação. Esta ideia é aplicável em todas as fases da reabilitação (Eckhardt et al., 2018).

A fim de fornecer os melhores cuidados e planear o melhor tratamento, o neurofisioterapeuta deve realizar uma avaliação completa dos problemas do utente. É a etapa mais importante no processo da fisioterapia, ajuda a orientar o raciocínio clínico e a tomar decisões informadas durante o processo de recuperação do utente. $O$ tratamento será tão bom quão boa for a avaliação na qual se baseou. Para que o neurofisioterapeuta garanta uma intervenção eficaz que contemple uma progressão que coincida com as necessidades do utente, a avaliação deve ser um processo contínuo e que ocorre diariamente antes, durante e após a intervenção. Resumindo, a intervenção em FN é indissociável da avaliação.

A Prática Baseada na Evidência (PBE) consiste em clinical reasoning and to offer physiotherapy services informed by the best scientific evidence available.

\subsection{APPROACH LEVEL}

The approach level corresponds to the transference of fundamental concepts to major ideas and guiding principles to clinical reasoning. Evidence-based guiding principles include inter-professional collaboration, person-centred care, 24-hour intervention, ongoing interplay of assessment and intervention and evidence-based practice (EBP).

Persons with neurological disorders commonly present a large and diverse number of complex and long-term problems across different disciplines and dimensions of health. This complexity requires a multi-professional team to address the person and the conditions. Each professional focuses on his or her specialty integrated in a global perspective of the situation. However, for a synergic and holistic approach, models of interprofessional collaboration are essential for efficacy and client benefits (Wade, 2020). The neurophysiotherapist must have a clear view of his or her professional identity, competencies and boundaries and understand all roles on a multi-professional team to optimize the physiotherapy role.

Person-centred care is a care philosophy that encourages and supports the person and related informal carer givers in the process of developing knowledge and trusted competencies to efficiently manage an individual's care and make decisions about his or her health. Two essential concepts associated with this philosophy are self-management and health promotion (Lennon et al., 2018), which need to be known by the physiotherapist, the person and related informal carers. Moreover, this approach requires an effective dialogue with continuous interaction between the physiotherapist and the person to a level that the person is engaged and part of the clinical decision-making throughout the whole process.

The twenty-four-hour approach promotes the transfer of skills and competencies learned during treatment sessions into daily life routines. All actors in the rehabilitation process include environmental adjustments and technical aid prescriptions. This approach should be applicable across all rehabilitation phases (Eckhardt et al., 2018).

For the best care and service delivery, the neurophysiotherapist should continuously and holistically assess the person's disabilities. This step is fundamental to steer clinical reasoning and to make contextualized decisions during the process. The treatment is proportional to the assessment accuracy. To ensure an efficient intervention that attains the person goals and potential, physiotherapy sessions should be an ongoing interplay of assessment and intervention. In short, NPT treatment is inseparable from the assessment.

Evidence-based practice (EBP) implies the raising of questions directed to the person's needs and sequentially the search and critical selection of scientific information for wellinformed clinical decision-making to address those needs. The translation into practice of scientific information is enhanced by the physiotherapist's clinical experience and expertise and by the person's values and beliefs. EBP also orients the neurophysiotherapist in making a prognosis with adequate SMART goals. 
levantar questões clínicas dirigidas às necessidades do utente e de seguida procurar, selecionar, avaliar e finalmente integrar as informações obtidas na tomada de decisão clínica. Para integrar a evidência científica na prática, também é necessário considerar a experiência clínica do fisioterapeuta (padrão de reconhecimento) e os valores e as preferências do utente. $A$ PBE também ajuda o neurofisioterapeuta a definir prognósticos com mais precisão e assim ser mais realista na definição de objetivos de intervenção.

\subsection{NÍVEL DOS MÉTODOS}

No nível dos métodos definem-se as linhas gerais para a operacionalização das ideias presentes na abordagem, é a fase de "o que vou fazer com o meu utente?". Neste nível temos 5 aspetos a considerar: a ativação da função, o treino orientado para a tarefa, o shaping, a repetição e o feedback.

Os dois primeiros aspetos, a ativação da função e o treino orientado para a tarefa, estão associados. Os neurofisioterapeutas focam-se no treino do controlo muscular voluntário e na promoção da aprendizagem das tarefas motoras essenciais. Um dos principais papéis do neurofisioterapeuta é ajudar o utente a vivenciar e a reaprender o movimento e a função. Os neurofisioterapeutas não estão apenas interessados em quais são as tarefas motoras que os utentes conseguem ou não realizar, mas também em como o utente se move (qualidade do movimento) durante a realização dessas tarefas. É sempre preferível priorizar a prática de atividades funcionais selecionadas em colaboração com o utente, no entanto, se o utente tem limitações que tornam difícil, ou até impossível, praticar essas tarefas, os terapeutas também podem abordar as limitações ou praticar movimentos específicos numa versão modificada. Em relação a isto a Berta Bobath disse "tornar a atividade possível, esperar a resposta, permitir que o movimento aconteça" (Eckhardt et al., 2018).

Shaping é um termo usado na neurorreabilitação e numa tradução literal significa "modelar". Neste contexto, modelar quer dizer ajustar a prática às capacidades funcionais do utente de forma a que ele consiga executar os movimentos pretendidos. Deste modo, o neurofisioterapeuta deve ajustar as sessões de intervenção às competências do utente, usando para tal as várias formas que tem para estruturar a prática: prática distribuída vs. prática intensiva, prática por partes vs. prática pelo todo, prática constante vs. prática variada.

Ativar determinado movimento e os respetivos circuitos neurais durante a execução de uma tarefa não é suficiente para conduzir a mudanças relativamente permanentes nesses circuitos. A repetição de determinado comportamento é essencial para induzir mudanças neuronais duradouras. A neuroplasticidade requer não apenas a aquisição de uma tarefa motora pelo recrutamento de determinado circuito neural, mas também a repetição contínua dessa tarefa ao longo do tempo (Thomas et al., 2017). A repetição é indispensável na prática para se alcançar um nível de melhoria e reorganização cerebral suficientes para que o utente continue a usar a função afetada fora das sessões, de forma a se manterem e obterem ganhos funcionais adicionais (Lohse, Lang, \& Boyd, 2014).

O feedback, tal como a repetição, é considerado uma variável que afeta a aprendizagem das tarefas motoras eé um dos

\subsection{METHODS LEVEL}

At the methods level, the general plan to implement the guiding principles is defined. Basically, the answer to the question "What am I going to do with that person?" should be planned around five aspects: restoring function, task-oriented training, shaping, repetition and feedback.

The first two aspects, restoring function and taskoriented training, are associated. Neurophysiotherapists focus on voluntary muscular activation integrated into basic and essential meaningful motor tasks.

This requires the neurophysiotherapist to help the person experience and relearn movement and function. Preferably, this training should provide the experience of a meaningful functional task for the person. However, when the disabilities are so severe that they prevent the initiation or the performance of a complete task, neurophysiotherapists might temporarily decompose the tasks into parts and/or modify them to a simpler motor control demand for the purpose of making components and respective functions possible. With regards to this, Berta Bobath stated, "make the activity possible, demand a response, allow the movement to happen" (Eckhardt et al., 2018).

Shaping is a neurorehabilitation technical term that implies the formation and modelling of functions. Physiotherapy means progressive training adjusted to the person's capabilities and the potential to generate the desired movements. For this, each NPT session should be structured around the following principles of graded practice: spaced practice vs. intensive practice; components practice vs. task practice and regular practice vs. randomized practice. However, making the movement possible and activating associated neural circuits during a functional task is not sufficient for a long-term duration of those achievements. Repetition is essential for the person to acquire long-term neural circuits. Durable motor programmes are dependent on long-term neuroplasticity, which is dependent on the continuous stimulus of the associated neural circuits (Thomas et al., 2017).

Repetition is therefore imperative for brain reorganization and functional outcomes to be maintained beyond physiotherapy sessions and to permit continuous functional gains in daily life (Lohse, Lang, \& Boyd, 2014).

Feedback is another essential factor that strongly influences the success of motor learning and is an obligatory strategy in NPT. Feedback could be verbal or nonverbal, such as manual handling and guidance. It has four effects frequently produced simultaneously, which cannot be isolated from each other. These are motivation, reinforcement, information and guidance (Kitago \& Krakauer, 2013).

\subsection{TECHNIQUES LEVEL}

This level is defined by how to implement the methods. In NPT, techniques are usually clustered into two groups: restorative and adaptive strategies. The first aims to restore or recuperate motor task performance to levels close to normal, while the second aims to implement adaptive strategies to compensate for lost functions that are not possible to restore, leading to adjusted performance (Balkaya \& Cho, 2019).

From a neurophysiological perspective, restoring means 
métodos fundamentais da intervenção do neurofisioterapeuta. O feedback dado pelo terapeuta pode ser verbal ou não-verbal (como por exemplo o handling) e tem quatro funções as quais são frequentemente produzidas simultaneamente e, por isso, é difícil separá-las. São elas a motivação, o reforço, a informação e a orientação (Kitago \& Krakauer, 2013).

\subsection{NÍVEL DAS TÉCNICAS}

Por fim temos o nível das técnicas, que é o nível onde se define o "como aplicar os métodos?". Podemos classificar as técnicas que o neurofisioterapeuta tem ao seu alcance em 2 grandes grupos: técnicas de recuperação e técnicas de compensação.

Em termos funcionais recuperação implica realizar a tarefa motora da mesma forma (ou muito parecida) da que se realizava antes da lesão, compensação, por outro lado, significa realizar a tarefa de uma forma diferente da que se realizava antes da lesão (Balkaya \& Cho, 2019).

Em termos neurofisiológicos recuperação significa (re) ativar os circuitos neuronais que foram danificados pela lesão e que executavam a função em causa antes da lesão e compensação significa ativar outros circuitos neuronais que não tinham a função que se pretende alcançar (Balkaya \& Cho, 2019).

A realidade da FN é que a recuperação e a compensação não devem ser consideradas separadamente e não são exclusivas uma da outra. Ou seja, o neurofisioterapeuta deve considerar os dois conjuntos de técnicas para que os utentes sejam capazes de recuperar tanto quanto possível. Sobretudo nos utentes que possuem limitações persistentes, o objetivo é continuar o trabalho em direção ao nível mais alto de funcionalidade e muitas vezes só se consegue alcançar esse nível através da combinação das duas.

\section{CONCLUSÃO}

O resultado final do NeuroQR é alertar os Neurofisioterapeutas para que não existe uma abordagem específica melhor do que outras, que possa ser aprendida ou investigada isoladamente. Existem sim, um conjunto de saberes teórico-práticos, representados no NeuroQR, que devem fazer parte do treino básico e da educação dos Neurofisioterapeutas. A FN requer uma abordagem holística, onde as decisões do terapeuta emergem da consideração de todo o NeuroQR, orientada para as competências e situação atual de cada utente.

Espera-se que a estrutura aqui apresentada seja um suplemento útil ao conhecimento atual e guie o raciocínio clínico e a tomada de decisão dos fisioterapeutas atuais e futuros.

\section{CONTRIBUIÇÕES AUTORAIS}

Conceptualização, H.S., I.B., P.A., R.B.; redação - preparação do draft original, H.S.; redação - revisão e edição, I.B., P.A., R.B. Todos os autores leram e concordaram com a versão publicada do manuscrito.

\section{REFERÊNCIAS/REFERENCES}

Balkaya, M., \& Cho, S. (2019). Optimizing functional outcome endpoints for stroke recovery studies. Journal of Cerebral Blood to reactivate or create new neural circuits to recuperate previous circuits with functions associated with a specific motor programme. Adaptive means to activate other circuits to perform other motor programmes to compensate for those lost (Balkaya \& Cho, 2019).

In NPT practice, both strategies are complementary and could be used simultaneously. Both should be considered in the different phases of rehabilitation to optimize higher levels of functional independence. This is highly relevant for persons with persistent disabilities and a slower progression in their rehabilitation path optimizing the recuperation window.

\section{CONCLUSION}

The NeuroQR framework aims to provide a frame of reference to guide the clinical reasoning associated with the decision-making of physiotherapists in the context of neurology. Instead of discussing the relevance of specific intervention approaches, this framework suggests a set of knowledge-guiding principles and competencies transversal to any approach that should be part of a neurophysiotherapist's training at the entry level and upgraded during continuous professional development. In summary, the NPT intervention requires a holistic approach where decision-making emerges from consideration of the different levels in the NeuroQR adjusted to the specific situation of each person.

\section{AUTHORSHIP CONTRIBUTIONS}

Conceptualization, H.S., I.B., P.A., R.B.; original draft, H.S.; revision and edition, I.B., P.A., R.B. All authors agree with the submitted version. 


\section{Artigo de Opinião | Opinion Article}

Flow \& Metabolism, 39(12), 2323-2342.

Dimitriadis, Z., Skoutelis, V., \& Tsipra, E. (2016). Clinical reasoning in neurological physiotherapy. Archives of Hellenic Medicine/Arheia Ellenikes latrikes, 33(4).

Eckhardt, G., Brock, K., Haase, G., Puschnerus, C., HengelmolenGreb, A., \& Böhm, C. (2018). Bobath Concept Structural Framework (BCSF): Positioning Partial Aspects Within a Holistic Therapeutic Concept. American Journal of Health Research, 6(4), 79-85.

Fell, D. W., Lunnen, K. Y., \& Rauk, R. P. (2018). Lifespan neurorehabilitation: A patient-centered approach from examination to interventions and outcomes. FA Davis.

Higgs, J., \& Jones, M. A. (2008). Clinical decision making and multiple problem spaces. Clinical Reasoning in the Health Professions, 3, 3-17.

Kitago, T., \& Krakauer, J. W. (2013). Motor learning principles for neurorehabilitation. Handbook of Clinical Neurology, 110, 93103.

Lennon, S., Ramdharry, G., \& Verheyden, G. (2018). Physical Management for Neurological Conditions E-Book. Elsevier Health Sciences.

Lohse, K. R., Lang, C. E., \& Boyd, L. A. (2014). Is more better? Using metadata to explore dose-response relationships in stroke rehabilitation. Stroke, 45(7), 2053-2058.

Michielsen, M., Vaughan-Graham, J. A., Holland, A., Magri, A.,

\& Suzuki, M. (2019). The Bobath Concept-A Model to Illustrate Clinical Practice: Responding to Comments on Michielsen Et Al. Disability and Rehabilitation, 41(17), 2109-2110.

Nielsen, G., Stone, J., Matthews, A., Brown, M., Sparkes, C., Farmer, R., ... Daniell, L. (2015). Physiotherapy for functional motor disorders: a consensus recommendation. Journal of Neurology, Neurosurgery \& Psychiatry, 86(10), 1113-1119.

Redondo, D. M. (2016). Abordagem, método e técnica: diálogos e duelos. Estudos Linguísticos (São Paulo. 1978), 45(2), 504-518.

Thomas, L. H., French, B., Coupe, J., McMahon, N., Connell, L., Harrison, J., ... Watkins, C. L. (2017). Repetitive task training for improving functional ability after stroke: a major update of a Cochrane review. Stroke, 48(4), e102-e103.

Wade, D. T. (2020). A teamwork approach to neurological rehabilitation. Oxford Textbook of Neurorehabilitation. Oxford University Press Oxford. 